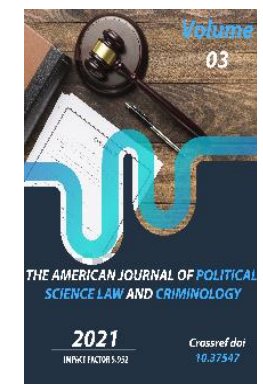

Copyright: Original content from this work may be used under the terms of the creative commons attributes 4.0 licence.

\section{Some Reflections On The Consideration By The Body Of Internal Affairs Of Appeals Of Mentally III Persons Or Persons With Mental Disorders}

\author{
Jamoldinov Humoyun Bakhtiyorbek Ugli \\ Lecturer, Department Of Administrative Law, Academy Of The Ministry Of Internal Affairs of \\ The Republic Of Uzbekistan
}

\title{
ABSTRACT
}

This article discusses the specifics of dealing with complaints from the mentally ill or mentally ill, the differences between the mentally ill or mentally ill, and the specifics of dealing with the incapacitated or disabled. The Law of the Republic of Uzbekistan "On Appeals of Individuals and Legal Entities" also stipulates that appeals of mentally ill or mentally ill persons, as well as incapacitated or partially incapacitated persons shall not be considered unless addressed by their guardians, trustees or legal representatives suggestions put forward.

\section{KEYWORDS}

Mentally ill, a person with a mental disorder, legal capacity, limitation of legal capacity, natural person, internal affairs body, appeal

\section{INTRODUCTION}

An appeal is an action that is communicated orally, in writing, and electronically to another person or public authority to satisfy a person's material or intangible (especially legal assistance) needs. People have been trying to meet their diverse needs throughout their 
lives. One of these is the need to protect their rights and legitimate interests. Individuals and legal entities apply to public authorities in the form of applications, complaints and proposals for the exercise of their legal rights and protection of their rights and legitimate interests. These individuals and legal entities enter into social relations through their appeals to public authorities. The legal literature defines social relations as follows: Social attitudes are relationships that people use in different areas of their life activities. Legally regulated social relations are considered as legal relations [1]. These social relations in our society are regulated by laws, by-laws, and such relations are legal relations. According to the literature, a legal relationship is the implementation of social relations through legal norms, subjects with rights and obligations. At the same time, it is a relationship between two specific individuals (individuals, legal entities) based on law and law [1]. In other words, a legal relationship is a relationship between individuals (i.e., citizens and legal entities) based on mutual legal subjective rights and obligations based on legal norms and specific legal facts. The main thing in the definition of a legal relationship is, first of all, to reflect the relationship between these parties. In such a relationship, at least two parties - the right holders - participate and enter into a dialogue [2].

\section{MATERIALS AND METHODS}

According to the spheres of law, that is, depending on the specificity of the norms of law to a particular field of law, legal relations are divided into the following types: state-legal (constitutional) relations; civil law relations; criminal relations; labour relations; administrative-legal relations; financial and legal relations, etc. [2].

Appeals of individuals and legal entities to government agencies are divided into administrative-legal or civil-legal relations according to their content. Because as a result of appeals of individuals and legal entities to state bodies on any issue, the parties (state bodies and individuals and legal entities) have rights and obligations. Appeals of individuals and legal entities to law enforcement agencies are regulated by the Law of the Republic of Uzbekistan "On appeals of individuals and legal entities", the Law of the Republic of Uzbekistan "On law enforcement agencies" and other laws and regulations [3, 4].

According to Article 6 of the Law of the Republic of Uzbekistan "On appeals of individuals and legal entities", several requirements are set for appeals. In particular: the application of an individual must contain the surname (name, patronymic) of the individual, information about his place of residence, the application of the legal entity must contain information about the full name of the legal entity, its location (postal address). The application of an individual or legal entity must contain the exact name of the state body, organization, position and (or) surname (name, patronymic) of the official to whom the application is addressed, as well as the essence of the application. Applications may include email addresses, contact telephone numbers and fax numbers of applicants. Appeals may be submitted in the state language and in other languages.

The written application must be certified by the signature of the applicant individual or the signature of the authorized person of the applicant legal entity. If it is not possible to 
confirm the written application of an individual with the signature of the applicant, this application must be certified by the signature of the person who wrote it, and his surname (name, patronymic) must be additionally written. Documents confirming the authority of the applicants are attached to the applications submitted through the representatives of the applicants [3].

The Company divides applicants (individuals and legal entities) according to their citizenship status into citizens of the Republic of Uzbekistan, stateless persons, foreign citizens, and legal entities are divided into legal entities registered in the territory of the Republic of Uzbekistan or registered abroad.

Individuals can also be divided into mentally retarded individuals, persons with temporary mental disorders (with limited legal capacity), and individuals with absolute mental disorders (incapacitated) based on their mental state. Human voluntary behaviour is generally regulated and controlled by the mind. A person's actions have a certain legal effect only when they are of a conscious nature. A person in a state of mental health can and must assess the circumstances in which his or her actions took place, understand the requirements placed on him or her, and decide whether or not to take a particular legal action. A person is considered sane if his mental state does not prevent him from making such a choice.

The sanity of a person is of great legal importance. Because the full understanding of the content of their appeals by individuals is of paramount importance in the timely consideration of appeals of individuals and legal entities by government agencies, the determination of the truth. After each appeal, government officials take certain actions. The sanity of the applicant is important not to waste time on the consideration of appeals by law enforcement officers, as well as to allow law enforcement officials to take the time to consider appeals of other individuals and legal entities in a timely manner. The sanity of individuals is important in all areas of law: especially criminal, administrative, civil, labour, and others. In criminal and administrative law, the sanity of a person is a criterion that must be taken into account when prosecuting and punishing a person.

The concepts of sanity and insanity are defined differently in legal literature. In particular, professors R. Kabulov and M. Usmonaliev say that "sanity is the ability of a person to understand the socially dangerous nature of his actions and control their actions during the commission of a crime." they assert that a person who is mentally aware of what he is doing and is able to control himself is rational. In this regard, B.O. Sarmanova also notes that mental sanity should be understood as a state of mind in which a person should understand the social significance of his actions at the time of the crime and be able to control them [6]. In our view, the authors have come to the above conclusions by approaching the concept of sanity only from the point of view of criminal law. However, mental retardation is also very important in civil law. Because in civil law, individuals and legal entities enter into contractual relations. In this case, the parties have certain rights and obligations. A conscious understanding of rights and obligations, and the exercise of them, requires a person's sanity. Mental retardation is a disorder of brain function. Mental infertility has legal and medical criteria. The legal criterion is formed in the law as the inability to feel or control the danger and evidence of their 
actions (inaction) to society, it has intellectual and volitional characteristics. The basis for finding a person mentally retarded depends on the medical criterion. It consists of chronic mental illness, temporary mood swings, mental retardation, and other types of mental disorders [7].

In our view, sanity is the state of mind of an individual at a certain stage of development, the age of socialization and self-awareness, self-awareness and self-management for mental health and actions, and then the ability to respond legally. The criteria of a person's sanity are based on two criteria, the first being a legal criterion and the second a medical criterion. The medical criterion is a generalized list of forms of mental illness, which consists of four groups that cover all cases of mental activity disorders:

1) Chronic mental illness;

2) Temporary mental disorder;

3) Mental weakness;

4) Other mental disorders.

Chronic mental illness combines persistent mental illness that tends to progress, i.e., the symptoms of the disease tend to grow more slowly or more rapidly. This group also includes diseases that can be similar to seizures, and in which the development of the disease process can stop, leaving a permanent mental defect. Diseases associated with this symptom of the medical criterion include schizophrenia, brain injury, epilepsy, and progressive paralysis. Temporary mental disorders are mental illnesses that last for a period of time and end in full recovery. Examples include reactive psychoses, alcoholic psychoses and emergencies (pathological intoxication, pathological affect, pathological sleep, etc.) [5].

The medical criteria for mental retardation also include mental retardation. These conditions are based on oligophrenia (congenital) or dementia (acquired), that is, mental retardation that develops as a result of a developing mental illness [5].

Other mental disorders include psychopathy and infantilism, that is, mental bondage. A person who, as a result of mental illness or mental disability, cannot realize the significance of his actions or control them, is recognized by the court as incompetent. In this case, a guardian or curator has appointed in relation to the person declared incapable. Guardians and trustees perform all actions on behalf of incapacitated persons. In particular, in accordance with the Law on Appeals of Individuals and Legal Entities, appeals in the interests of minors, incapacitated and partially incapacitated persons can be submitted by their legal representatives in the manner prescribed by law and considered in the manner prescribed by law [3].

Treatment failure, like mental retardation, is determined only when medical and legal criteria are met. Just as the legal criterion in criminal proceedings supplements and regulates the medical criterion, the presence of mental illness or mental retardation in civil proceedings does not give grounds to assert that a person is incapable of self-medication. Only the mentally ill or mentally retarded and unable to reasonably perform their work are considered incapacitated. The medical criteria for mental retardation also include mental retardation. These conditions are based on oligophrenia (congenital) or dementia (acquired), that is, mental retardation that 
develops as a result of a developing mental illness [5].

Other mental disorders include psychopathy and infantilism, that is, mental bondage. A person who, as a result of mental illness or mental disability, cannot realize the significance of his actions or control them, is recognized by the court as incompetent. In this case, a guardian or curator has appointed in relation to the person declared incapable. Guardians and trustees perform all actions on behalf of incapacitated persons. In particular, in accordance with the Law on Appeals of Individuals and Legal Entities, appeals in the interests of minors, incapacitated and partially incapacitated persons can be submitted by their legal representatives in the manner prescribed by law and considered in the manner prescribed by law [3].

Treatment failure, like mental retardation, is determined only when medical and legal criteria are met. Just as the legal criterion in criminal proceedings supplements and regulates the medical criterion, the presence of mental illness or mental retardation in civil proceedings does not give grounds to assert that a person is incapable of self-medication. Only the mentally ill or mentally retarded and unable to reasonably perform their work are considered incapacitated.

V.P. Serbian about legal capacity is nothing more than a legal phrase designed to reflect a certain state of mind. He argues that a person who does not understand the meaning of the action he is performing may not be able to act. In our opinion, the scientist came to this conclusion only from the criminal-legal point of view [5].
The legal capacity of citizens is studied in the following groups:

- Completely incapacitated (children under 6 years old, recognized by the court as mentally ill and mentally retarded);

- Artial legal capacity (minors from 6 to 18 years old);

- Limited legal capacity;

- Full legal capacity (sane citizens over 18 years old and emancipated and married before 18 years old).

Kh. Rakhmonkulov divides minors under 18 into two categories, considering them partially suitable for treatment. Some authors propose to divide the legal capacity of citizens into groups with full legal capacity, persons with direct legal capacity (14-18 years old), persons with limited legal capacity, partially capable persons (young children under 14 years of age), persons with full legal capacity. legal capacity [7].

Completely incapacitated, that is, children under the age of 6 , are persons who are recognized by the court as mentally ill and mentally retarded and are not fully aware of their behaviour. Therefore, actions taken on their behalf must be carried out by guardians or trustees.

Partial legal capacity is the partial legal capacity of minors between the ages of 6 and 18. In this category of everyday life, people enter into small transactions, in some cases related to labour social relations, and, of course, turn to the state. agencies. The presence of a legal representative in the applications of this category of persons is mandatory since persons between the ages of six and eighteen do not fully understand and do not understand their actions. Thus, the condition for the 
participation of legal representatives is enshrined in the law. Disability means that the legal capacity of a person whose social life is violated, and the category of a person who puts his family in a difficult financial situation as a result of alcohol or drug abuse, can be limited by the court in accordance with the civil procedural law. It is sponsored. Such a citizen has the right to independently conclude small business transactions. He can enter into other agreements with the consent of the sponsor, as well as receive and manage wages, pensions and other income. However, such a citizen is independently responsible for the transactions he has made and for the damage caused to him. In case of cancellation of the grounds for restricting the legal capacity of a citizen, the court shall cancel the restriction of his legal capacity. Sponsorship of a citizen is cancelled by a court decision [8].

Behaviour is a legal concept based on a specific mental state of the subject. A citizen cannot be treated for mental illness or mental incapacity, or limitation of legal capacity falls within the competence of only the court, and the participation of a prosecutor in such cases is mandatory. If there is sufficient evidence of mental illness or mental retardation, the court orders a forensic psychiatric examination to determine the mental state of the person in preparation for the case before the issue is resolved. According to the conclusion of the expert examination, the citizen is recognized by the court as incapable or partially incapable, and a guardian or curator is appointed in relation to him. Although the law guarantees the right of minors, guardians or legal representatives to apply to state bodies in the interests of incapacitated or incapacitated persons, the law does not regulate cases of incapacitated persons turning to their state bodies.

\section{RESULTS AND SUGGESTIONS}

In practice, there are cases today when a mentally ill or mentally ill person turns to the police. Although in practice such appeals are rare, the procedure for their consideration is not stipulated by law. In this regard, in our opinion, it is advisable to make the following amendments to part 1 of article 29 of the Law of the Republic of Uzbekistan "On appeals of individuals and legal entities". "The following appeals are not considered:

- Anonymous appeals;

- Applications submitted through representatives of individuals and legal entities, in the absence of documents confirming their powers;

- Appeals of persons recognized as mentally ill or mentally ill by a court decision, as well as incapacitated or partially incapacitated (if their guardians, trustees or legal representatives did not apply);

- Applications that do not meet other requirements established by this Law.

Because civil law provides that a court can invalidate a contract concluded by a citizen who has become incapacitated or incapacitated as a result of alcohol or drug abuse, without the consent of his guardian or trustee.

\section{CONCLUSION}

Thus, as a result of the proposed amendment of part 1 of article 29 of the Law of the Republic of Uzbekistan "On appeals of individuals and legal entities", the following can be achieved:

First, the legislation establishes the procedure for considering appeals of the mentally ill or 
mentally ill, as well as incapacitated or partially incapacitated persons, fills in the gaps in the law and unifies the law with the norms of civil law.

Secondly, as a result of the rule that government agencies do not consider appeals of the mentally ill or mentally ill, as well as incapacitated or incapacitated persons, civil servants do not spend too much time considering such appeals, but instead consider appeals from other citizens. appeals in a timely manner and in full, sufficient withdrawal time is ensured.

\section{ACKNOWLEDGEMENT}

The authors acknowledge the immense help received from the scholars whose articles are cited and included in references to this manuscript. The authors are also grateful to authors/editors/publishers of all those articles, journals and books from where the literature for this article has been reviewed and discussed.

\section{REFERENCES}

1. U. Tajikhanov, A.Kh. Saidov, Yu.S. Pulatov \& at all. (2011). Legal encyclopedia. Tashkent, Shark. p.135, 512.

2. H.T.Odilqoriev, I.Tulteev, N.P.Azizov \& at all. (2009). Theory of State and Law: Textbook, Tashkent. Academy of the Ministry of Internal Affairs of the Republic of Uzbekistan, p. 314.

3. LRU-445[ЎPҚ-445-соH] 11.09.2017. "On appeals of individuals and legal entities". (2017, September 12). lex.uz. https://lex.uz/docs/3336169

4. LRU-407 [ЎРҚ-407-сон] 16.09.2016. On Internal Affairs Bodies. (2016,
September 17). lex.uz. https://lex.uz/docs/3027843

5. Kh. N. Yallaev (2012). Forensic Psychiatry. Vol. 2. Textbook. Tashkent, Academy of the Ministry of Internal Affairs of the Republic of Uzbekistan. p. 20.

6. A A.A. Otazhonov and D.M. Kushbakova. (2020). The concept and criteria of mental retardation, as well as issues of improving the norms of criminal law for their regulation. Legal Bulletin, Legal, social, scientific and practical journal. 1(2). pp. 75-76.

7. Zokirov I.B. (2009). Textbook "Civil Law". Vol. 1. Revised and supplemented fifth edition. Tashkent State Law Institute. pp.148-149.

8. 21.12.1995. Civil Code of the Republic of Uzbekistan Part 1. Article 31. (1995, December 21). lex.uz. https://lex.uz/docs/111189\#151153 